\begin{tabular}{|c|c|c|}
\hline & $\begin{array}{c}\text { Jurnal Teknologi Kimia Unimal } \\
\text { http://ojs.unimal.ac.id/index.php/jtk }\end{array}$ & $\begin{array}{l}\text { Jurnal } \\
\text { Teknologi } \\
\text { Kimia } \\
\text { Unimal }\end{array}$ \\
\hline
\end{tabular}

\title{
Desulfurisasi dan Penyerapan Merkuri secara Simultan dari Batubara Peringkat Rendah (Aceh Barat) untuk Aplikasi Power Plant dengan Adsorben Zeolit
}

\author{
Yuanda Wattimena ${ }^{1}$, Asri Gani ${ }^{2 *}$, Medyan Riza² \\ ${ }^{1}$ PT Pupuk Iskandar Muda, Jl. Banda Aceh-Medan, Aceh Utara, 24352 \\ $2^{*}$ Program Studi Magister Teknik Kimia, Universitas Syiah Kuala \\ Jl. Syech Abdurrauf No.7 Banda Aceh 23111 \\ *e-mail: asri.gani@che.unsyiah.ac.id
}

\begin{abstract}
Abstrak
Adsorpsi emisi pembakaran batubara dengan menggunakan adsorben zeolit pada jenis briket dan pulverized telah dilakukan. Penelitian ini bertujuan untuk mengurangi emisi gas $\mathrm{SO}_{2}$ dan logam $\mathrm{Hg}$ yang berbahaya apabila rilis di udara bebas dengan cara menggunakan adsorben zeolit untuk kecendrungan emisi menjadi bottom ash yang lebih terkendali. Pengujian ini fokus mengevaluasi rasio optimal rasio adsorben terhadap jumlah batubara terhadap performa penyerapan, sehingga penggunaannya tidak mengurangi nilai bakar batubara. Prosedur pembakaran ekspremintal awal dimulai dari pencampuran batubara dan zeolit dengan rasio 4\%, 6\%, 8\%, 10\% dan 12\% yang dibagi dalam bentuk briket dan pulverized. Kedua jenis sampel dibakar secara berurutan pada electrical stainless steel reaction tube furnace pada kondisi temperatur pembakaran Fludized Bed Coal Combustion yaitu $600^{\circ} \mathrm{C}, 700^{\circ} \mathrm{C}$, dan $800^{\circ} \mathrm{C}$ dengan laju alir udara disesuaikan. Flue gas hasil pembakaran yang keluar dari outlet dianalisa menggunakan Gas Combustion and Emission Analyzer (E4400, E-Instrument). Logam $\mathrm{Hg}$ yang yang diserap oleh zeolit pada Bottom Ash dianalisa menggunakan NIC Mercury SP Anlayzer. Hasil pengujian menunjukan kinerja zeolit terhadap kapasitas penyerapan logam $\mathrm{Hg}$ untuk pembakaran batubara pulverized pada temperatur pembakaran $600^{\circ} \mathrm{C}, 700^{\circ} \mathrm{C}$ dan $800^{\circ} \mathrm{C}$ masing-masing didapat pada angka 33,6, 19,25 dan 9,97 ppb/gr serta pada pembakaran briket batubara masing-masing didapat sebesar 59,83, 37,8 dan 24,22 ppb/gr. Secara simultan untuk mengurangi emisi $\mathrm{SO}_{2}$ dan logam berat $\mathrm{Hg}$ pada fly ash untuk temperatur pembakaran Fludized Bed Coal Combustion rasio optimum berkisar antara 6\%-8\% adsoben zeolit dari jumlah massa batubara Kaway XVI Kabupaten Aceh Barat.
\end{abstract}

Kata kunci: adsorpsi, fluidized bed combustion, zeolit, briket, pulverized

\section{Pendahuluan}

Batubara merupakan alternatif penggunaan energi pada industri-industri menengah keatas seperti pabrik pupuk dengan memproduksi amoniak berbahan baku gas alam sebagai respon berkurangnya cadangan hidrokarbon pada dekade ini. Penggunaan gas alam tidak terbatas pada proses produksi amoniak, tetapi juga 
digunakan untuk menghasilkan utilitas, seperti pembangkit steam atau kukus. Kenaikan harga gas alam dan keterbatasan cadangan membuat PT Pupuk Iskandar Muda perlu memikirkan alternatif energi lain yaitu batubara sebagai aplikasi power plant.

Secara umum batubara dapat dikategorikan berdasarkan nilai kalori, kandungan air, dan kandungan karbon. Beberapa pengotor yang terkandung dalam batubara antara lain abu dan logam-logam berat dalam jumlah yang sangat kecil (Mucjidin, 2009). Kandungan merkuri yang berlebih pada air, tanah dan udaramemiliki dampak pada kesehatan manusia dalam jumlah besar dan berulang dapat menybabkanbkesehatan yang fatal, khusunya saat ini asia timu dan tenggara merupakan penyumbang $40 \%$ dari emisi merkuri ke udara (Giang et al, 2015 \& KLHK, 2015)

Potensi batubara di Indonesia saat ini sekitar $85 \%$ berasal dari Low Rank Coal (batubara peringkat rendah) dan di Provinsi Aceh tepatnya di Meulaboh, Aceh Barat tersedia \pm 500 juta ton batubara low rank (LPSIPA, 2012). Karakteristik kandungan sulfur pada batubara Aceh sendiri tergolong tinggi yaitu mencapai 0,28\% db (Mahidin, 2009).

Beberapa industri di Provinsi Aceh telah memanfaatkan sumber energi batubara sebagai bahan baku pembangkit listrik dan steam diantaranya PT. Lafarge Holcim Indonesia, Lhoknga. Batubara peringkat rendah adalah jenis batubara yang memiliki nilai kalor rendah (<6000 cal/g) dan kandungan moisture yang tinggi namun jenis batubara ini mempunyai harga yang ekonomis dibandingkan dengan batubara jenis antracite atau bituminous.

Hasil pembakaran batubara menghasilkan emisi yang mempengaruhi lingkungan dan kesehatan manusia. Emisi utama yang dihasilkan dari pembakaran batubara adalah Sulfur dioksida $\left(\mathrm{SO}_{2}\right)$, Nitrogen oksida $\left(\mathrm{NO}_{\mathrm{x}}\right)$, Partikulat, Karbon dioksida $\left(\mathrm{CO}_{2}\right)$, logam berat yang terdapat pada Fly ash dan Bottom Ash yang merupakan residu yang terjadi ketika batubara dibakar.

Peraturan Pemerintah Nomor 41 Tahun 1999 tentang Pengendalian Pencemaran Udara terutama $\mathrm{SO}_{2}$ dan merkuri dimana pembangkit steam 
diharuskan menggunakan peralatan desulfurisasi gas buang, untuk membersihkan sulfur sebelum meninggalkan cerobong asap (stack). Emisi logam-logam berat juga harus dihilangkan. Peralatan-peralatan yang dapat mengurangi polutan diantaranya $\mathrm{SO}_{2}$ (desulfurizer), $\mathrm{NOx}$ (catalytic converter), dan materi partikulat.

Untuk menurunkan potensi polutan yang dihasilkan dari pembakaran batubara kualitas rendah salah satunya dengan menggunakan adsoben berbasis Al/Si yaitu Zeolit (Maurstad, 2005). Massa adsorben sebagai penyerap yang mendekati optimum dalam banyak penelitian adalah berkisar antara 5\% untuk adsorben batu kapur (Chen, 2011) dan 5\% zeolit untuk pembakaran 1,5 $\lambda$ (stoichiometric air ratio) serta 10\% untuk kaolin berbasis kalsium dengan 1,2 $\lambda$ (Yao, 2005). Efesiensi penghilangan SO2 menggunakan zeolit 5A dapat mencapai hingga $20 \mathrm{mg} / \mathrm{g}$ atau 20\% (Liu, 2010).

Dalam sistem pembakaran batubara dalam penelitian ini adalah dengan pengkondisian secara Fluidized Bed Combustion (FBC). Pada sistem FBC pembakaran batubara terjadi di dalam Fluidized Bed dengan tambahan suplai aliran udara dari bagian bawah bed. Bed tempat terjadinya pembakaran dapat dikatakan punya sifat seperti fluida dengan kecepatan udara yang cukup untuk mempertahankan bed dalam keadaan fluidisasi serta dengan tingkat pencampuran yang tinggi (Oka, 2004).

Proses FBC dapat membakar batubara yang mengandung $85 \%$ bahan inert dengan retensi $\mathrm{SO}_{2}$ yang efektif dari penambahan batu kapur (limestone) (Saxena and Jotshi, 1994). Proses ini juga menghasilkan emisi NOx dalam jumlah sedikit yang memenuhi standar lingkungan sehingga teknologi ini punya keunggulan terhadap proses lain seperti PC (Leckner, 2013). FBC juga efektif untuk pemanfaatan batubara dengan kualitas rendah (Karakas et al., 2013).

Penggunaan zeolit sebagai adsrorben logam berat yang sering digunakan di perusahaan dan pusat pengelohan limbah adalah arang aktif dan zeolit yang mudah didapatkan secara komersil. Karakteristik dari zeolit sendir tahan terhadap kondisi thermal yang tinggi dan kemampuan menyerapnya yang baik. Proses adsorpsi pada suatu adsorben zeolit yang berupa adsoben berbasi $\mathrm{Al} / \mathrm{Si}$ 
terutama terjadi pada pori-pori kecil (micropore). Sedangkan macropore hanya berperan sebagai tempat transfer adsorbat dari permukaan luar ke micropore (Bhatnagar \& Minocha, 2006).

Kajian ini dilakukan sebagai alternatif penyerapan $\mathrm{SO}_{2}$ dan Merkuri pada proses pembakaran batubara peringkat rendah yang berasal dari Batubara Kaway XVI, Kabupaten Aceh Barat menggunakan adsorben zeolit sebagai bahan bakar pembangkit steam dan listrik (power plant) di PT. Pupuk Iskandar Muda kedepannya.

\section{Bahan dan Metode}

Bahan dan peralatan yang digunakan dalam penelitian ini antara lain: batubara (berasal dari Kaway XVI Kabubaten Aceh Barat), Zeolit alam dan larutan additive khusus untuk analisa merkuri. Sedangkan peralatan yang digunakan meliputi Crusher, Ball mill, Vibrating screen, Mesin press briket, Compressor, wet gas meter, Electric tube furnace, Desiccator, Ceramics boat, NIC Mercury SP Anlayzer, Timbangan elektrik dan Industrial gas combustion and emission analyzer (E4400, E instrument)

Batubara dihaluskan menggunakan crusher hingga ukuran partikel dihomogenkan hingga mencapai -60 mesh. Dibuat campuran batubara dan zeolit ukuran -120 mesh untuk masing-masing variasi rasio perbandingan. Selanjutnya sample dibuat sebagian briket yang dicetak dan Pulverized.

Alat disusun sesuai dengan skema rangkaian seperti pada Gambar 1.1 yang ditunjukan pada skema alat pembakaran (Furnace Tube Electric 120). Kemudian diatur laju alir pembakaran dengan dikondisikan kebutuhan udara pembakaran sesuai kebutuhan yang telah dihitung stoichiometric air ratio sesuai spesifikasi batubara tersebut. Sampel yang telah dipersiapkan sebelumnya diletakan di Ceramics Boat untuk kemudian dimasukan ke dalam stainless steel reaction tube pada Tube Furnace electric 120. Untuk mengantisipasi panas yang hilang diperlukan pemasangan Isolasi dan jaket pada kedua keluaran stainless steel reaction tube. Kemudian Furnace electric 120 dihidupkan serta diatur waktu dan temperatur pembakaran sesuai dengan variabel penelitian. 
Pembakaran sampel di Furnace electric 120 dilengkapi dengan Industrial gas combustion and emission analyzer (E4400, E instrument) untuk menganalisa $\mathrm{SO}_{2}$ yang terlepas melalui keluaran stainless steel reaction tube sejak awal pembakaran sehingga dapat diketahui kecendrungan sulfur yang terlepas ke udara sesuai variabel waktu. Analisa Bottom Ash dilakukan untuk mendapatkan konsentrasi logam Hg menggunakan NIC Mercury SP Analyzer.

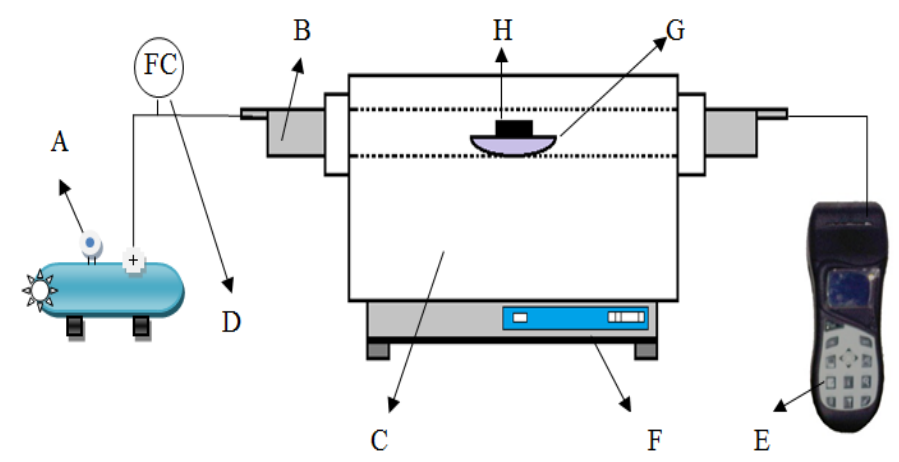

Keterangan Gambar :

A. Kompresor (penyedia udara)

B. Stainless steel Reaction

Tube

C. Electrically Furnace

D. Flow Meter

E. Industrial gas combustion

and emission analyzer

F. Set profil pembakaran

G. Ceramics Boat

H. Sampel Batubara

Gambar 1. Skema Alat Pembakaran dan Analisa $\mathrm{SO}_{2}$

Penyerapan unsur logam dan emisi lainnya pada pembakaran batubara terjadi secara simultan dimana tidak terjadinya selektivitas atau kecenderungan terhadap unsur-unsur tertentu. Sehingga perlu ditinjau kapasitas adsorbsi untuk unsur yang paling sulit dikendalikan sehingga dapat mewakili penyerapan unsurunsur yang lain. Kapasitas adsorbsi menggambarkan kamampuan penyerapan terhadap adsorbat pada tiap gram adsorben. Dimana nilai tesebut dapat menjadi acuan jumlah adsorben optimum yang akan kita gunakan dalam skala yang lebih besar untuk penggunaan zeolit ini sendiri. Kapasitas adsorpsi ditentukan menggunakan persamaan berikut:

$$
Q=\frac{\mathrm{Ca}-\mathrm{Ca}_{0}}{M_{\text {adsorben }}}
$$

Keterangan :

Q

$\mathrm{Ca}_{0}$

$\mathrm{Ca}$
$=$ kapasitas penyerapan $(\mathrm{ppm} / \mathrm{g})$

= konsentrasi awal logam tanpa adsorben

$=$ konsentrasi adsorbat dengan variasi rasio adsorben 
Madsorben = massa adsorben yang digunakan dengan membandingkan nilai kapasitas adsorpsi dari tiap-tiap rasio zeolit yang digunakan maka akan didapat kapasitas optimum pada rasio-rasio tertentu.

\section{Hasil dan Diskusi}

\subsection{Profil $\mathrm{SO}_{2}$ Pada Proses Pembakaran Batubara}

Sebelum mengalami oksidasi, batubara akan mengalami proses inisiasi oksigen yang teradsorpsi kedalam komponen volatile matter sebagai pemicu. Volatile matter ini akan sangat mudah teroksidasi dan diikuti dengan meningkatnya temperatur terus menerus yang akhirnya mengakibatkan terjadinya pembakaran spontan (Saptoadi, 2004).

Pada gambar 2 dapat dilihat Emisi gas $\mathrm{SO}_{2}$ mengalami puncaknya pada awal-awal pembakaran batubara, hal ini disebabkan oleh oksidasi Volatile Matter yang berlangsung diawal pembakaran. Konsentrasi $\mathrm{SO}_{2}$ selanjutnya menurun seiiring dengan pembakaran Fix Carbon. Hal ini menyebabkan sulfur pada batubara merupakan komponen Volatile Matter. Emisi $\mathrm{SO}_{2}$ yang dihasilkan oleh pembakaran batubara dalam bentuk Pulverized lenih tinggi dibandingkan briket pada berbagai temperatur. Hal ini disebabkan luas permukaan batubara Pulverized

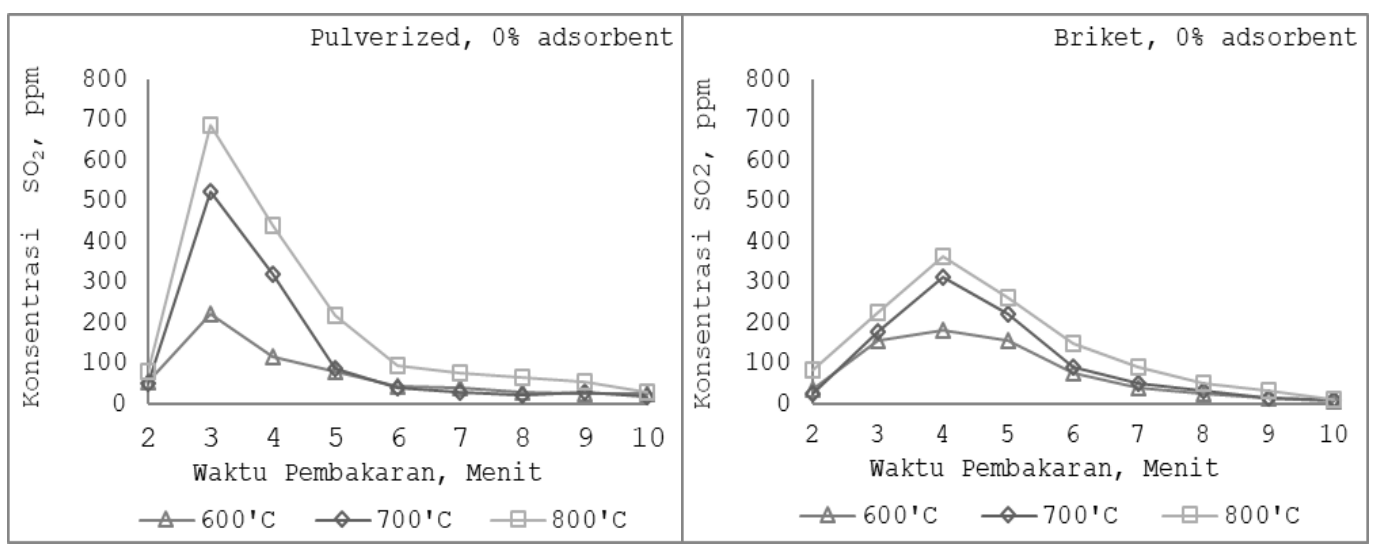

Gambar 2 Profil pembakaran batubara tanpa adsorben terhadap emisi $\mathrm{SO}_{2}$ yang dihasilkan pada pembakaran sampel

lebih besar dibandingkan dengan briket sehingga laju difusi oksigen lebih cepat pada Pulverized dibandingkan briket. Semakin tinggi temperatur maka akan semakin tinggi konsentrasi $\mathrm{SO}_{2}$ yang dihasilkan dari proses pembakaran 
tersebut. Hal yang sama juga mengindikasikan bahwa pembakaran dalam bentuk Pulverized cenderung lebih sempurna dibandingkan briket.

\subsection{Pengaruh Jumlah Adsorben Terhadap Pengurangan Emisi $\mathrm{SO}_{2}$}

Emisi $\mathrm{SO}_{2}$ yang dihasilkan dengan adanya adsorben disajikan pada gambar 3 (a), (b) dan (c) baik untuk briket maupun Pulverized. Konsentrasi $\mathrm{SO}_{2}$ yang dihasilkan semakin menurun seiiring dengan meningkatnya adsorben. Efek penambahan adsorben jelas terlihat pada kondisi Pulverized khususnya pada Gambar 3 (a) dan 3 (b) terjadinya penurunan yang sangat signifikan dengan konsentrasi $\mathrm{SO}_{2}$ tanpa adsorben dengan adanya $4 \%$ adsorben.

Emisi $\mathrm{SO}_{2}$ yang terbentuk pada pembakaran briket lebih rendah dibandingkan Pulverized disebabkan perbandingan penyerapan $\mathrm{SO}_{2}$ antara kedua sampel yang berbeda dengan ukuran partikel Pulverized jauh lebih besar dibandingkan briket. Semakin banyak adsorben, semakin sedikit $\mathrm{SO}_{2}$ yang lepas ke udara dan ini menunjukkan dampak penyerapan $\mathrm{SO}_{2}$ oleh zeolit. Luas permukaan sangat mempengaruhi kecepatan oksidasi $\mathrm{SO}_{2}$, akan tetapi dengan oksidasi yang seketika tersebut menyebabkan beban zeolit menyerap $\mathrm{SO}_{2}$ cenderung tinggi pada awal-awal pembakaran. Hal ini mengacu pada faktor yang mempengaruhi laju reaksi dimana semakin besar luas permukaan bidang sentuh antar partikel, maka tumbukan yang terjadi semakin banyak, sehingga menyebabkan laju reaksi semakin cepat. Ditinjau dari mekanisme oksidasi dari luas permukaannya briket dapat dilihat cenderung lebih landai antara tanpa adsorben dengan penambahan adsorben dibandingkan penyerapan untuk Pulverized. Beban zeolit semakin meningkat akibat laju reaksi yang dipengaruhi luas kontak sehingga waktu tinggal untuk proses adsorpsi semakin cepat.

Mekanisme penyerapan $\mathrm{SO}_{2}$ oleh zeolit ditinjau dari kandungan ion-ion utama di dalam zeolit yaitu $\mathrm{K}^{+}, \mathrm{Na}^{+}, \mathrm{Ca}^{2+}$ atau $\mathrm{Mg}^{2+}$ dimana kandungan ion-ion terjadi pertukaran (ion exchange) dengan $\mathrm{SO}_{2}$ sehingga terbentuk senyawasenyawa garam. Senyawa garam yang terbentuk tersebut bersifat sulit teroksidasi secara termal. Proses penyerapan selanjutnya terjadi ketidaksetimbangan gayagaya pada molekul-molekul senyawa garam tersebut sehingga gaya kohesi 
cenderung lebih besar dari pada gaya adhesi. Ketidaksetimbangan gaya-gaya tersebut menyebabkan senyawa garam cenderung terserap oleh pori-pori zeolit yang bersentuhan pada permukaannya. Hal ini menjadi pertimbangan faktor waktu tinggal yang diupayakan selama mungkin sehingga senyawa garam cenderung bersetuhan lebih lama dengan elemen macropore pada permukaan zeolit yang menyebabkan penyerapan terjadi lebih optimum (Ding dan Bathia, 2003).

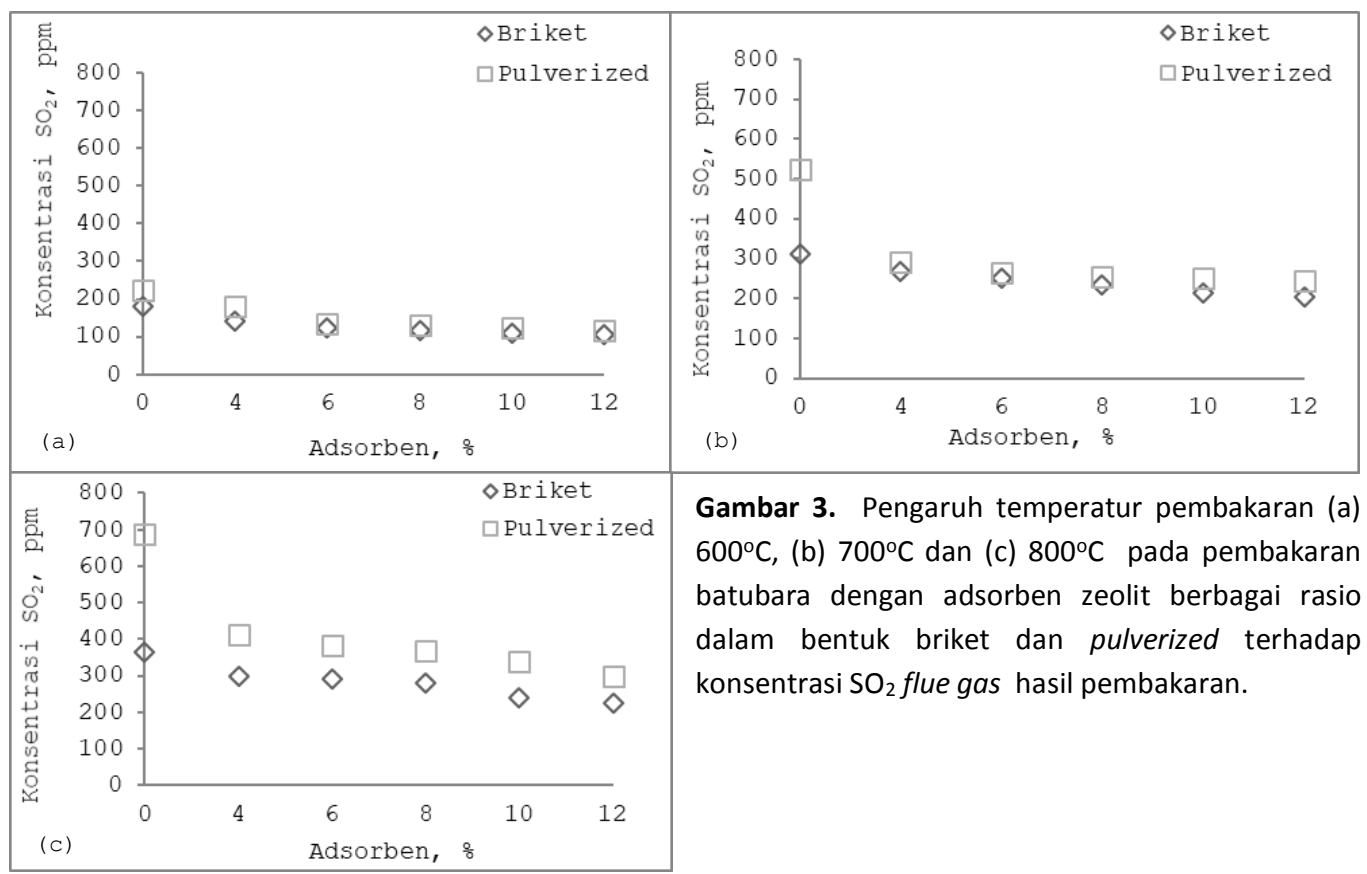

\subsection{Pengaruh Jumlah Adsorben Kandungan Merkuri pada Bottom Ash}

Penambahan zeolit bertujuan untuk mereduksi kadar logam berat yang terlepas sebagai abu terbang (fly ash), sehingga cenderung terikat oleh zeolit dan tertinggal menjadi abu sisa (Bottom Ash). Emisi yang dihasilkan dari pembakaran batubara sangat dipengaruhi oleh cara terbentuknya, elemen-elemen yang saling berkaitan dengan elemen organik dan fraksi sulfida cenderung menguap (fly ash), dan kombinasi elemen berbahan mineral lebih memungkinkan menyisakan debu (Bottom Ash) (Xu et al., 2003). Oleh karena itu, dengan penambahan zeolit sebagai adsorben diharapkan terjadi afinitas atau gaya tarik-menarik antara logam berat dengan mineral melalui fenomena adsorpsi. 
Pada gambar 4 (a), (b) dan (c) tingkat konsentrasi logam Hg pada Bottom Ash cenderung lebih tinggi pada briket dibandingkan dengan Pulverized. Pengaruh luas permukaan menjadi faktor utama adanya perbedaan konsentrasi logam $\mathrm{Hg}$ yang tertinggal pada batubara.

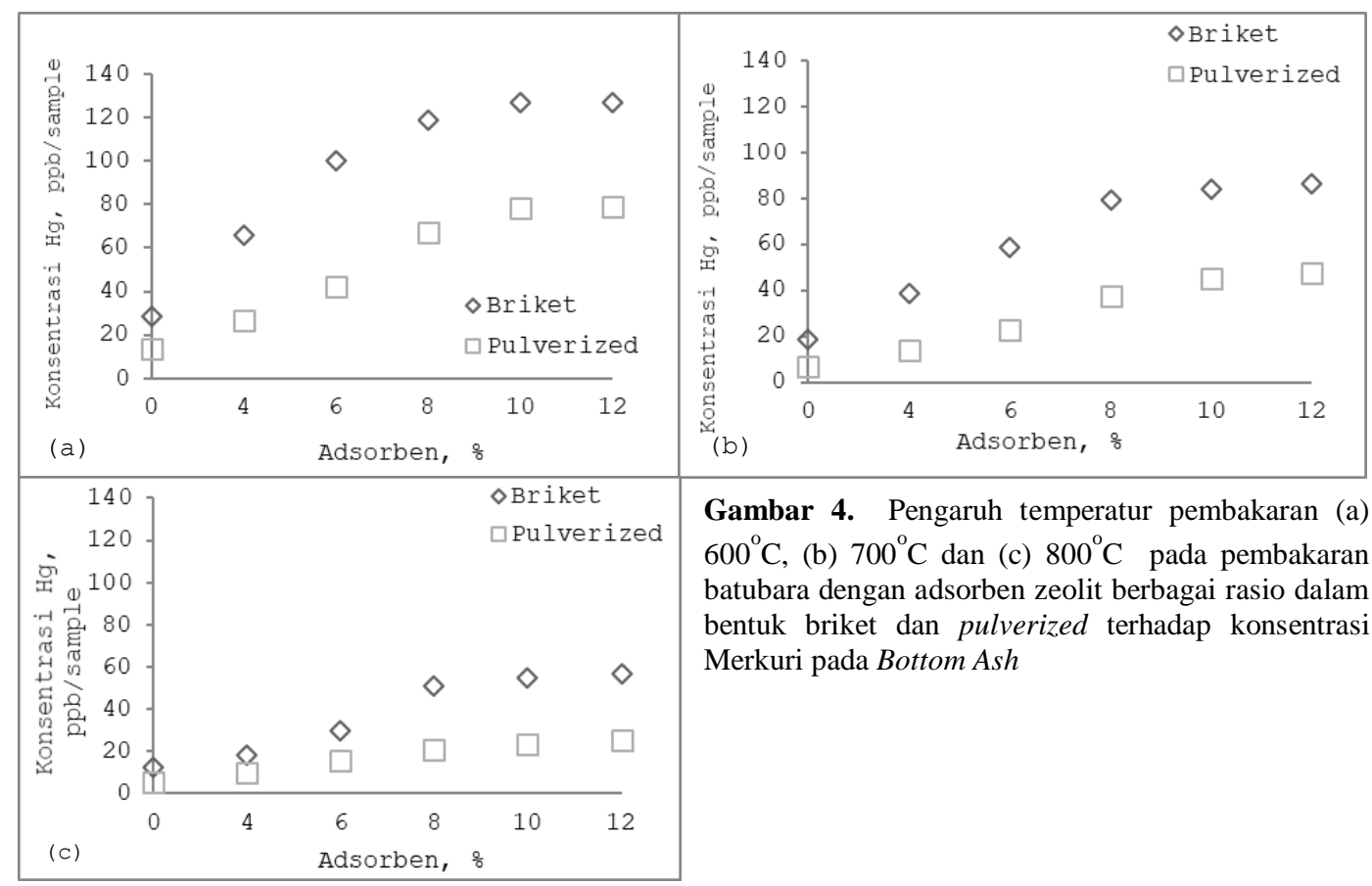

Walaupun memiliki tingkat volatilitas yang tinggi unsur $\mathrm{Hg}$ tetap masih terdapat pada Bottom Ash, hal tersebut dikarenakan adanya kandungan sejumlah Particulate Bound Mercury (Hgp) dari karbon yang tidak terbakar pada Bottom Ash dari pembakaran batubara (Wilcox et al., 2012).

Untuk Pulverized sendiri yang luas permukaannya lebih besar. Logam Hg lebih mudah teroksidasi sehingga beban zeolit lebih tinggi terhadap proses perpindahan massa kedalam pori-porinya dikarenakan laju penguapan pada saat proses oksidasi lebih cepat jika dibandiungkan dengan briket. Untuk briket dengan luas permukaan dan karakteristik yang lebih kompak menyebabkan proses oksidasi senyawa volatile matter $(\mathrm{Hg})$.

\subsection{Kapasitas Adsorpsi Zeolit}


Briket memiliki karakteristik yang kompak dengan luas permukaan yang kecil dibandingkan batubara Pulverized berpengaruh terhadap proses oksidasi senyawa-senyawa batubara yang akan menjadi emisi. Singkatnya proses pengoksidasi untuk briket cenderung lebih lama dan kecendrungan panas yang dihasilkan lebih landai dibandingkan Pulverized. Pada Gambar 5(a) performa zeolit pada temperatur $600^{\circ} \mathrm{C}, 700^{\circ} \mathrm{C}$ dan $800^{\circ} \mathrm{C}$ masing-masing didapat sebesar 59,83, 37,8 dan, 24,22 ppm/gr.

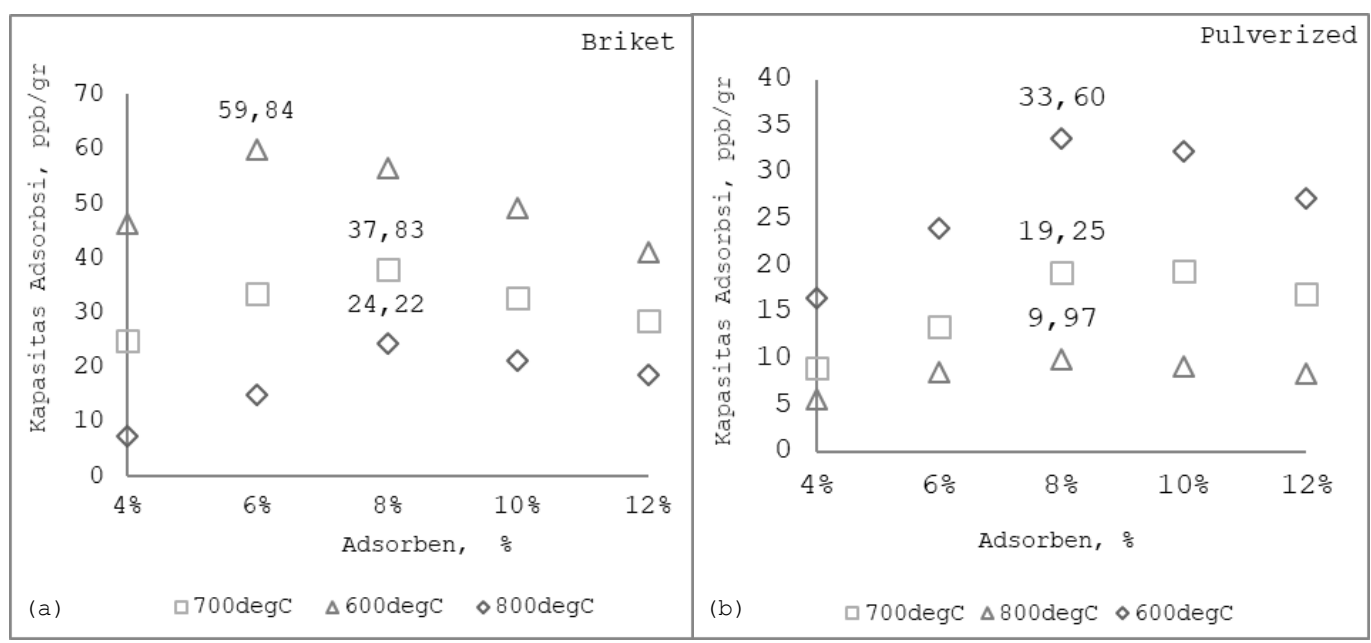

Gambar 5. Kapasitas adsorben zeolit terhadap penyerapan merkuri pada pembakaran batubara Pulverized (a) dan Briket (b).

Pengaruh temperatur sendiri terhadap performa adsorben cukup signifikan, pada temperatur $600^{\circ} \mathrm{C}$ hingga $800^{\circ} \mathrm{C}$ penurunan kapasitas mencapai lebih dari $50 \%$. Penurunan tersebut menjadi acuan bahwasanya performa zeolit sendiri berkurang pada temperatur semakin tinggi. Untuk nilai rasio yang memenuhi kapasitas penyerapan optimum didapat pada 6\%-8\% massa zeolit terhadap batubara pada penggunaanya dalam bentuk briket.

Pada pembakaran Pulverized memiliki karakteristik luas permukaan kontak dengan udara oksidasi lebih besar dibandingkan dengan briket batubara. Hal itu membuat beban oksidasi menjadi lebih cepat dan besar dibandingkan dengan briket yang diteruskan dengan kecepat emisi yang dihasilkan dari pembakaran. Kecepatan oksidasi tersebut membuat residence time penyerapan 
oleh zeolite berkurang sehingga performaa adsorben dalam menyerap per massa zeolit tidak sebaik pada kondisi briket.

Pada Gambar 5(b), Nilai kapasitas penyerapan logam Hg per gram zeolit pada temperatur $600^{\circ} \mathrm{C}, 700^{\circ} \mathrm{C}$ dan $800^{\circ} \mathrm{C}$ kapasitas adsorpsi didapat mencapai 33,6, 19,25 dan 9,97 ppm/gr. Jika dibandingkan dengan performa zeolit pada briket yang mencapai $59,83 \mathrm{ppm} / \mathrm{gr}$ terjadi margin performa yang signifikan. Hal tersebut menjadi acuan bahwasanya dalam penggunaan batubara Pulverized ini emisi yang dihasilkan sulit untuk dikendalikan dengan menggunakan teknologi sistem fluidized bed combustion (FBC) yang cenderung memiliki waktu tinggal yang cepat. Akan tetapi pertimbangan lain penggunaan bahan bahan batubara dalam bentuk Pulverized seperti menggunakan ukuran mesh lebih besar yang dapat menambah nilai residence time yang menjadi solusi dalam penggunaannya dalam bentuk Pulverized.

\section{Simpulan dan Saran}

Penambahan adsorben zeolit terbukti mengurangi kandungan $\mathrm{SO} 2$ dan logam $\mathrm{Hg}$ dalam flue gas, dimana hal tersebut menunjukkan meningkatnya konsentrasi emisi tersebut pada Bottom Ash yang lebih mudah dikendalikan. Untuk pembakaran Pulverized cenderung sulit dikendalikan dimana tingkat oksidasi senyawa volatile matter lebih tinggi dibandingkan dengan sampel briket, dimana luas permukaan oksidasi sampel pulvurized lebih besar dibandikan sampel briket. Performa zeolit pada penggunaanya dalam pembakaran briket dan Pulverized batubara didapat kapasitas penyerapan optimum pada rasio 6\%-8\%. Penambahan adsorben menurunkan nilai kalori dari batubara. Pada variabel penelitian ini yang mencapai $12 \%$ zeolit/komponen inert, nilai kalori tersebut masih didalam klasifikasi kalori sub-bituminus, tidak menurunkan grade nilai bakar batubara.

\section{Daftar Pustaka}

Bailey, D.W. and P.H.M Feron. 2005. Post-combustion Decarbonisation Processes. Oil and Gas Science and technology Rev. IFP, Vol. 60, No. 3.

Yan Liu, Teressa M Bison, 2010, Recent developments in novel sorbents for flue gas 
clean up Department of Chemical and Materials Engineering, University of Alberta, Edmonton, Alberta, Canada.

Giang, A., Stokes, L. C., Streets, D.G.,Corbitt, et al .(2015). Impact of the minamata convention on mercury emission and global deposition from coal-fired power generation in Asia. Environmental Science and Technology, 49(9), pp. 5326-5335

Mahidin, Khairil, Adisalamun dan Asri Gani, 2012, Modeling and Simulation on NOx and $\mathrm{N}_{2} \mathrm{O}$ Formation in Co-combustion of Low-rank Coal and Palm Kernel Shell Jurnal Rekayasa dan Lingkungan, Volume 9 No.2, 2012.

Wilcox, J., E. Rupp, S.C. Ying, D. Lim, A.S. Negreira, A. Kirchofe, F. Feng, K. Lee. 2012. Mercury Adsorption and Oxidation in Coal Combustion and Gasification Processes. Elsevier Science Publishers B.V. Amsterdam. International Journal of Coal Geology 90-91 (2012) 4-20.

Saptoadi, H., 2004, Combustion Characteriastics Of Fuel Briquettes Made From Wooden Saw Dust And Lignite. The International Workshop On Biomass And Clean Fossil Fuel Power Plan Technology 2004. Jakarta Indonesia. pp186-199.

Yao,H., Naruse,I., 2005. Control of trace metal emissions by sorbents during coal combustion, Department of Ecological Engineering, Toyohashi University of Technology, Tempaku-cho, Toyohashi 441-8580, Japan

Wang,J., Zang,Y., Han, L., Chang, L., Bao, W., 2013 Simultaneous Removal of Hydrogen Sulfide and Mercury from Simulated Syngas by Iron Based Sorbents

Karakas, E., P. Grammelis, G. Skodras, P. Vourliotis. 2013. Fluidized Bed Combustion With The Use of Greek Solid Fuels. Thermal Science: Vol. 7, No. 2, pp. 33-42.

Leckner, B. 2013. Fluidized Bed Combstion Research and Development in Sweden. Thermal Science, Vol. 7, No. 2, pp. 3 - 16.

Speight. James G, 1994, The Chemistry and Technology of Coal, Marcel Dekker. Inc. New York. Page-569.

Jyh-Cheng Chen, Ming-Yen Wey, Yao-Chi Lin. The Adsorption of Heavy Metals by Different Sorbents Under Various Incineration Conditions

Muchjidin, 2006. Pengembalian Mutu dalam Industri Batubara, Jilid 1 Edisi Pertama, ITB: Bandung.

Yan Liu, Teressa M Bison, 2010, Recent developments in novel sorbents for flue gas clean up. Department of Chemical and Materials Engineering, University of Alberta, Edmonton, Alberta, Canada.

Chen, J., Wey, M., \& Lin, Y. (1998). The Adsorption of Heavy Metals by Different Sorbents Under Various Incineration Conditions. Chemosphere, Vol. 37, No. 13. Elsevier Science Ltd.

Xu, M., R. Yan, C. Zheng, Y. Qiao, J. Han, C. Sheng. 2013. Status Of Trace Element Emission In A Coal Combustion Process: A Review. Fuel Processing Technology 85 (2003) 215- 237.

Maurstad, O., H. Herzog, O. Bolland, J. Beér. 2005. Impact of Coal Quality and Gasifier Technology on IGCC Performance. Norwegian University of Science and Technology (NTNU), Norway. 
Oka, S.N. 2004. Fluidized Bed Combustion. Marcel Dekker Inc., New York.

Bhatnagar, A. and A.K. Minocha. 2006. Conventional and Non-conventional Adsorbents for Removal of Pollutants from Water - A Review. Indian Journal of Chemical Technology. 